\title{
Novelty of Plant Functional Approaches under Weed-crop Interactions Particularly Leaf Functional Traits of the Wheat Crop: A Synthesis
}

\author{
Amandeep Kaur, Abhishek Kumar, Meenu Patil, Pardeep Kumar, A. N. Singh* \\ Soil Ecosystems and Restoration Ecology Lab., Department of Botany, Panjab University, India
}

Received June 27, 2020; Revised September 7, 2020; Accepted September 17, 2020

\section{Cite This Paper in the following Citation Styles}

(a): [1] Amandeep Kaur, Abhishek Kumar, Meenu Patil, Pardeep Kumar, A. N. Singh, "Novelty of Plant Functional Approaches under Weed-crop Interactions Particularly Leaf Functional Traits of the Wheat Crop: A Synthesis," Advances in Zoology and Botany, Vol. 8, No. 6, pp. 469 - 482, 2020. DOI: 10.13189/azb.2020.080601.

(b): Amandeep Kaur, Abhishek Kumar, Meenu Patil, Pardeep Kumar, A. N. Singh (2020). Novelty of Plant Functional Approaches under Weed-crop Interactions Particularly Leaf Functional Traits of the Wheat Crop: A Synthesis. Advances in Zoology and Botany, 8(6), 469 - 482. DOI: 10.13189/azb.2020.080601.

Copyright $\bigcirc 2020$ by authors, all rights reserved. Authors agree that this article remains permanently open access under the terms of the Creative Commons Attribution License 4.0 International License

\begin{abstract}
Plant functional traits integrate the ecological and evolutionary history of a species, and can potentially be used to predict its response as well as its influence on ecosystem functioning. Understanding its mechanistic role for community assembly can provide evidence to understand weed-crop interactions, and in particular, how weeds impact on crop production. In this article, we tried to explain the various traits specifically leaf functional traits (LFTs) used to know the level of competition between crop and weeds under the agro-ecosystem. To accomplish this, we synthesized the available information by carrying out a literature survey and standardized protocols from available databases showing the variation in the respective traits of crop and weeds. And, it is found that there are certain specific LFTs such as leaf area, leaf size and specific leaf area are helpful to calculate the level of competition under weed crop interactions. So, these traits proved to be a good tool to screen out species for productivity and ecological performance in the species interactions. This confirms with previous findings that knowledge to measure the LFTs can improve the yield in response to weed competition and can be implemented by the farmers in the field. Also, this array of traits can help to minimize the use of different chemicals (weedicides, herbicides and pesticides) in weeds management under agro-ecosystems which affect the biotic factors such as soil biota. However, more studies are required to explore the utility of these traits under
\end{abstract}

weed-crop interactions in the agro-ecosystems.

Keywords Weeds Wheat, Weed-crop Interaction, Phalaris spp., Avena spp., Chenopodium spp., Leaf Functional Traits

\section{Introduction}

Functional traits are perhaps need-based modifications that determine the trade-off between organisms and abiotic components. These traits defined the structural, chemical, physiological or phenological properties of plants and plant parts, which mechanistically put an impact on plant performance (i.e. growth, survival and reproduction) across ecological gradients [1]. Research on plant functional traits i.e. whole-plant traits, root traits, shoot traits, leaf traits, reproductive or yield traits have been critical in proceeding our understanding of the structure and function of agro-ecosystems [2]. Also, these can be used to investigate the performance of organisms towards local environmental conditions wherein they are; in addition, how they play their role in terms of structural and functional attributes with an ecosystem. Normally, a plant is composed of five basic components viz. leaf, stem, root, inflorescence and fruit. Each component plays its responsibilities to cope up with environmental conditions. 
These are responsible for the capture and use of solar energy to determine vegetable productivity. In fertile-productive environments, the ability to allocate soil resources to leaf production is characteristic of highly competitive species [3]. Out of these groups of traits, leaf functional traits have established the most attention by ecologists and plant eco-physiologists.

Further, wheat is one of the major food crops in the world which globally occupies about 17 percent of the cropped land and contributes to 35 percent of the staple food $[4,5,6]$. India is the second-largest producer of wheat in the world contributing about 94.88 million tonnes of grains with a productivity of $2.98 \mathrm{t} \mathrm{ha}^{-1}$ from the area of 31.5 million hectares [7]. In India, the rice-wheat cropping system achieves 80 percent of food requirement and 60 percent of the nutrition requirement of the Indian population and specifically major parts of the Indo-Gangetic plains [5]. Out of total rice and wheat production in India, 42 percent comes from Indian Gangetic plains comprising Punjab, Haryana, Uttar Pradesh, Bihar and West Bengal. The productivity data indicates an increasing trend for the period 1958-1998, but a decreasing and stagnating trend afterwards [8], but the continuously increasing population indicates the shortage of food supply for upcoming generations. It is one of the most important cereal crops in many parts of India but, the productivity of wheat is mainly limited by the presence of weeds which consume essential plant nutrients, moisture and solar energy and compete with the crop for space.

\section{ENVIRONMENTAL EFFECTS}
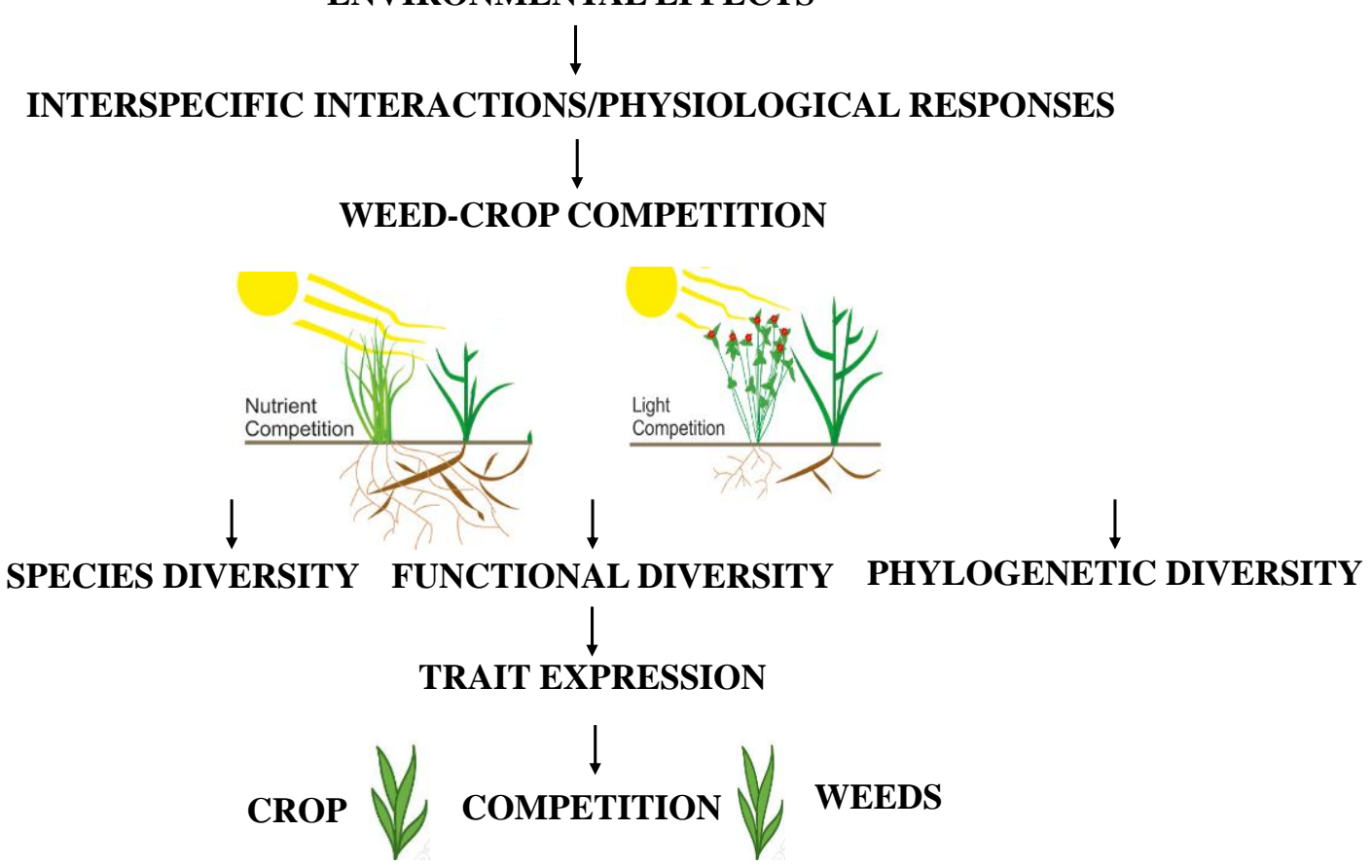

LEAF FUNCTIONAL TRAITS

Figure 1. The schematic picturization of weed-crop competition using trait-based ecology 

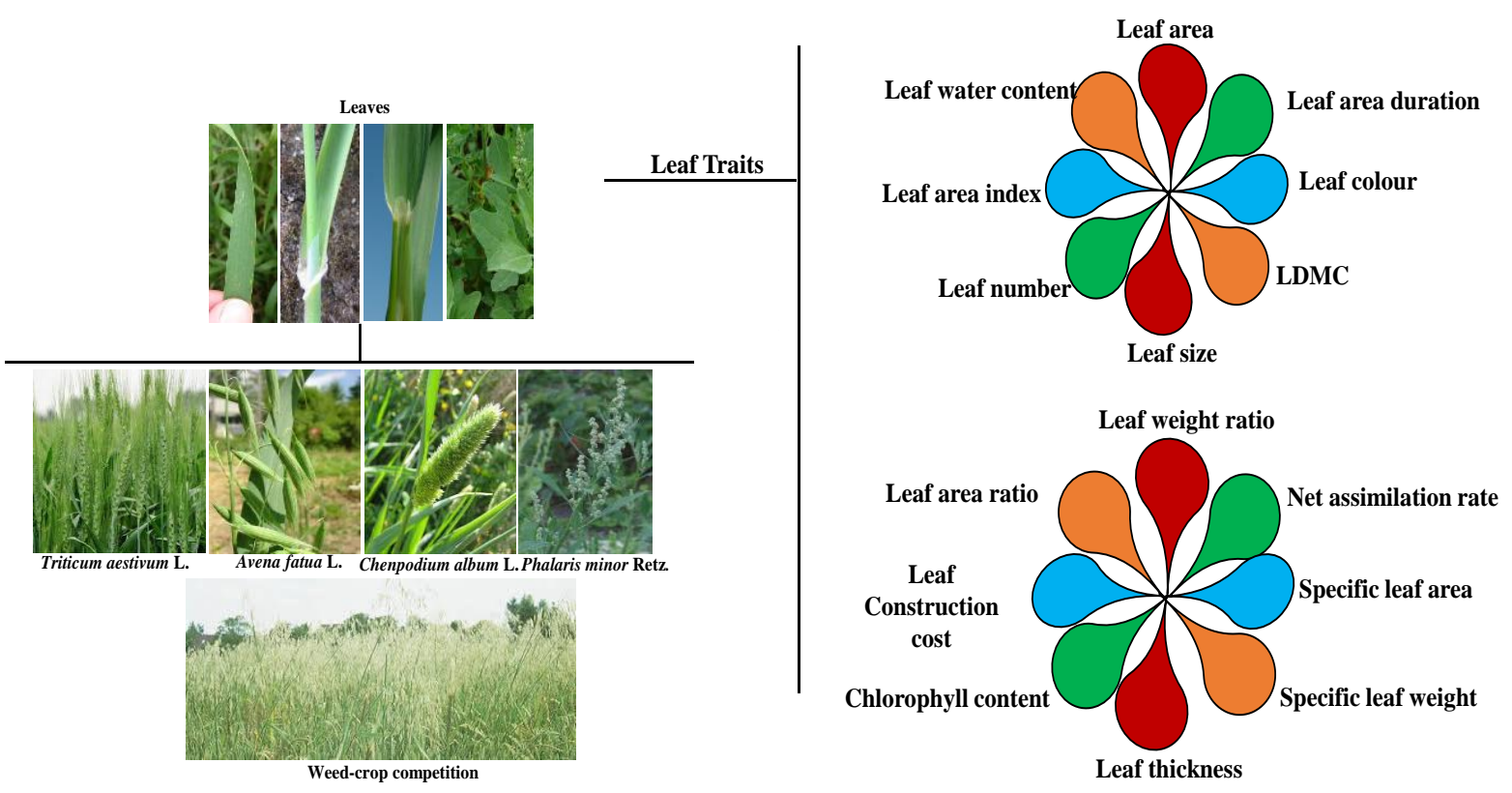

Figure 2. The schematic picturization of various leaf functional traits under weed-crop interaction

Despite important advances in the field, prominent researchers have contended that as a discipline, research on alternative agricultural systems lacks theoretical advances that provide appropriate predictive competition ability among species. To address this issue, there have been several reviews discussing and outlining conceptual road maps for research into alternative agricultural strategies. These reviews demonstrate that agricultural research historically and currently pursues to understand weed competition responses to crop which is a novel approach to agricultural research, based on trait-based ecology (Figure1). To minimize the use of different chemicals management (For instance weedicides and pesticides) under agro-ecosystems which affect biotic factors such as soil biota. Our goal in this paper was to discuss by contextualizing and defining morphological leaf trait-based agricultural research in a changing environment. We seek to do so by reviewing published literature to illustrate the weed-crop competition (troublesome weeds particularly Avena, Phalaris and Chenopodium sps.) using leaf functional traits (Figure 2).

\section{Materials and Methods}

We complemented the data by searching the data-base structured literature search using the Web of Science, Science Direct, Google Scholar, Mendeley etc. Specifically, we collected peer-reviewed literature for the term 'leaf', 'leaf functional', traits, wheat, weeds and so on coupled with traits names (e.g. 'leaf area', leaf area index', 'specific leaf area' and 'leaf weight ratio'). We also searched for species names coupled with the physiological terms (e.g. 'wheat' and 'weeds name') and also grey matter on different search engine viz. Google. The full text of each article was then searched for these terms along with grey matter from different search engines. We then found studies which include field-based, greenhouse and growth chamber experiments, and where sampling protocols in the studies followed (at least approximately) followed standardized functional trait collection methodologies. Any deviations from these protocols were noted in the tabular form (Table 1).

\section{Weeds of the Wheat Crop}

Wheat (Triticum aestivum L.) crop is infested with both grassy and broad-leaved weeds such as Parthenium hysterophorus, Portulaca oleracea, Euphorbia mollis, Amaranthus viridis, Convolvulus arvensis, Commelina benghalensis, Chenopodium album, Cyperus rotundus, Sonchus arvensis etc.

The major weeds prevalent in wheat fields are dicot and monocot weeds grown in Rabi season viz. Bathua (Chenopodium album), Gazari (Fumaria parviflora), Katili (Cirsium arvense), Krishn Neel (Anagallis arvensis), Akari (Vicia hirsuta), Sengi (Melilotus alba/Melilotus indica), Chatarimatari (Lathyrus aphaca), Satyanashi (Argemone mexicana) etc. Likewise, monocot weeds viz., Gehusa/Gullidanda / Gehunka mama (Phalaris minor), wild oats (Avena fatua), Piazi (Asphodelus tenuifolius) etc. impose a serious problem in wheat fields. Weeds result in a minimum of $40 \%$ yield loss in wheat in India [9] and are the major constraint in agricultural production systems. It is estimated that more than one-third of the total field losses due to the biotic stresses caused by weeds alone and often unnoticed due to their multi-prolonged hidden 
effects on plant growth [10]. Some weeds are discussed which are commonly found in the wheat fields of Indian agriculture. General characteristics of selected weeds of the wheat crop were described in the table (Table 2).

\subsection{Leaf Traits of $P$. minor}

Phalaris minor Retz. (little seed canary grass) is a dominant and most serious winter annual grass weed of wheat-rice cropping systems in the north-western Indo-Gangetic Plains of India [11,12,13,14]. At the early stage of growth, it is very difficult to differentiate between P. minor and wheat plants. However, on careful observation, the leaves probably light green basal portion of this weed is pink in colour compared to dark green leaves and basal portion of the wheat crop and maintained throughout the life cycle of the weed except at maturity. It has a white and pointed ligule. Comparison to this, wheat has a prominent auricle and a very poorly developed ligule. The sheath at the base of P. minor often exudes a red pigment when broken at the base. It has an erect stem with distinct nodes and internodes and at maturity, the plants are taller than wheat. Leaves are linear with finely pointed tips, ligule exceptionally long (about $1 \mathrm{~cm}$ long) that clasp the stem. The aggressiveness of P. minor is due to its morphology and by their growth requirement, which is similar to those of wheat [15]. It is a major problem in the states of Haryana, Punjab and Uttar Pradesh [16].
There are four different species of the genus Phalaris that often grow as weeds on cultivated land i.e. P. paradoxa, $P$. minor, $P$. brachystachys and $P$. arundinaceae. Consequently, $P$. minor has become a ubiquitous weed, infesting more than 16 million hectares of wheat in northern India [17].

\subsection{Leaf Traits of Avena spp.}

Avena is an annual tufted grass with erect culms. Plant height varies from 25 to $120 \mathrm{~cm}$. Blades are dark green, grow up to $40 \mathrm{~cm}$ and show a membranous ligule, which is 1 to $6 \mathrm{~mm}$ long and often irregularly toothed. Sheaths are smooth or slightly hairy, especially in younger plants. The ligule is membranous of $1-6 \mathrm{~mm}$ long and irregularly toothed. The sheaths are smooth and slightly hairy whereas the ligule of wheat is very small and it consists of two hairy leaf ears/auricles. The leaf colour of Avena fatua is long dark green and that of wheat is dark green. The leaf size of Avena is $10-40 \mathrm{~cm}$ long and $3-15 \mathrm{~cm}$ wide. It is widely distributed among the temperate regions of southern Europe, northern Africa and south-western Asia, including the Arabian Peninsula and the Indian subcontinent and also in Ethiopia, Kenya, South Africa, and Australia as well as the western hemisphere: Argentina, Costa Rica, Ecuador, Mexico, Peru, Uruguay, and United States.

Table 1. Measurement and parameterization of some of the leaf functional traits

\begin{tabular}{|c|c|c|}
\hline $\begin{array}{l}\text { Leaf functional } \\
\text { traits }\end{array}$ & Protocols & References \\
\hline Leaf number & $\begin{array}{l}\text { Count and record the number of leaves on each plant. Count every visible leaf on the plant, } \\
\text { including the tips of new leaves just beginning to emerge. }\end{array}$ & (86) \\
\hline Fresh weight $(\mathrm{g})$ & Weigh the harvested leaves & \\
\hline $\begin{array}{l}\text { Dry weight of leaf } \\
(\mathrm{g})\end{array}$ & Fresh leaves were harvested and oven-dried at $85^{\circ} \mathrm{C}$ for 48 hours to determine the dry weight. & \\
\hline Leaf size $(\mathrm{cm})$ & Measure the height and maximum width of the leaf with the help of a measuring scale or tape. & \\
\hline Leaf Area $\left(\mathrm{cm}^{2}\right)$ & $\begin{array}{l}\text { Trace the leaves on graph paper and count the squares covered to give you an estimate of the } \\
\text { surface area for each leaf } \\
\qquad \text { OR }\end{array}$ & (87) \\
\hline $\begin{array}{l}\text { Leaf dry matter } \\
\text { content }\left(\mathrm{mg} \mathrm{g}^{-1}\right)\end{array}$ & $\begin{array}{l}L A=\text { length } \times \text { max. breadth } \times k ; \text { where } k \text { is a constant } \\
\qquad L D M C=\frac{\text { oven dry weight of leaf }}{\text { fresh leaf weight }}\end{array}$ & (88) \\
\hline \multirow{3}{*}{ Leaf area index } & $L A I=\frac{L A}{\text { land area }} ;$ where LA is Leaf area & \multirow{3}{*}{ (89), (90) } \\
\hline & $\begin{array}{c}\text { LAI }=\text { Leaf area per plant } \times \text { No of plants } \mathrm{m}^{-2} \\
\text { crop height }(\mathrm{m})\end{array}$ & \\
\hline & $L A I=\frac{\times \text { number of tillers per } m^{2}}{100}$ & \\
\hline $\begin{array}{l}\text { Leaf area duration } \\
\qquad\left(\mathrm{cm}^{2} \text { day }^{-1}\right)\end{array}$ & $\begin{array}{l}\qquad \mathrm{LAD}=\frac{(\mathrm{LA} 1+\mathrm{LA} 2)(\mathrm{T} 2-\mathrm{T} 1)}{2} \\
\mathrm{LA} 2 \text { and LA1 is leaf area of upper } 2^{\text {nd }} \text { successive leaf at intervals of } 10 \text { days } \mathrm{T} 1 \text { and } \mathrm{T} 2 \text { just } \\
\text { before booting }\end{array}$ & (89), (91) \\
\hline $\begin{array}{l}\text { Average unit leaf } \\
\text { area }\end{array}$ & $\mathrm{ULR}=\left[\frac{\mathrm{W} 2-\mathrm{W} 1}{L A 2-L A 1}\right]\left[\frac{\ln L A 2-\ln L A 1}{T 2-T 1}\right]$ & (92) \\
\hline
\end{tabular}




\section{Table 1 Continuous}

Leaf weight ratio $(g$ $\left.\mathrm{g}^{-1}\right)$

Leaf area ratio $\left(\mathrm{cm}^{2}\right.$ $\left.\mathrm{g}^{-1}\right)$

Leaf equivalent water thickness ( $\mathrm{g}$ $\mathrm{cm}^{-2}$ )

Specific leaf area $\left(\mathrm{cm}^{2} \mathrm{~g}^{-1}\right)$

Net assimilation rate $\left(\mathrm{g} \mathrm{cm}^{-2} \mathrm{~d}^{-1}\right)$

Leaf thickness $(\mu \mathrm{m}$ or $\mathrm{mm}$ )

Chlorophyll content

Saturation leaf water deficit (\%)

Leaf relative water content (\%)

Leaf life span

Leaf construction cost (g glucose $\left.\mathrm{g}^{-1}\right)$

$$
\begin{gathered}
\text { LWR }=\frac{\text { Leaf biomass }}{\text { Total biomass }} \\
L A R=\frac{\text { Area of leaf }}{\text { Total Plant weight }} \\
L E W T=\frac{\text { Fresh wt. }- \text { Dry wt. }}{\text { Leaf Area }} \\
S L A=\frac{\text { Area of leaf }}{\text { Drywt.of Leaf }} \\
\text { total dry matter } \\
\text { Lth }=\frac{1}{\text { leaf area duration }}
\end{gathered}
$$

SLA- specific leaf area, LDMC- Leaf dry matter content

Chlorophyll content can be measured by many methods.

(92), (93), (94)

(94), (95)

To calculate chlorophyll content as $\mathrm{mg} / \mathrm{g}$ of tissue the following equations were used.

$$
\begin{aligned}
& \text { Chlorophyll a }\left(\frac{\mathrm{mg}}{\mathrm{g}}\right)=12.7\left(\text { OD 663) }-2.69(\text { OD } 645) \times\left(\frac{v}{1000 \times w t .}\right)\right. \\
& \text { Chlorophyll } b\left(\frac{\mathrm{mg}}{\mathrm{g}}\right)=22.9(\text { OD } 645)-4.68(\text { OD } 663) \times\left(\frac{v}{1000 \times w t .}\right)
\end{aligned}
$$

$$
\text { Total chlorophyll } \frac{\mathrm{mg}}{\mathrm{g}}=20.2\left(\text { OD645) }+8.02(\text { OD663 }) \times\left(\frac{v}{1000 \times w t}\right)\right.
$$

$\mathrm{OD}=$ Optical Density at certain Wavelength (645 or $663 \mathrm{~nm}), \mathrm{V}=$ Final Volume $(10 \mathrm{ml})$, Wt. $=$ Weight of sample $(100 \mathrm{mg})$

Where, Tp- the period of leaf production, Tl-period of leaf loss, T- time lag between the end of leaf production and beginning of leaf loss

$$
\text { 1. } L C C=\frac{\left[(0.06968 H c-0.065)(1-A)+7.5\left(\frac{k N}{14.0067}\right)\right]}{E g}
$$

where $H c$ is the ash-free heat of combustion $\left(\mathrm{kJ} \mathrm{g}^{-1}\right), A$ is the ash concentration $\left(\mathrm{g} \mathrm{g}^{-1}\right), k$ is the oxidation state of the nitrogen source ( +5 for nitrate or -3 for ammonium), $N$ is the organic nitrogen concentration $\left(\mathrm{g} \mathrm{g}^{-1}\right)$ and $E g$ is the growth efficiency.

$$
\text { 2. } L C C=\left(-1.041+\frac{5.077 C}{100-M}\right)(1-M)+5.325 \mathrm{Norg}
$$

where $\mathrm{LCC}$ is the total cost to produce one gram of plant biomass (g glucose/g dry weight), Cthe carbon content of the organic biomass $\left(\mathrm{g} \mathrm{g}^{-1}\right), \mathrm{M}$ and Norg the mineral and organic nitrogen content of the total dry weight $\left(\mathrm{g} \mathrm{g}^{-1}\right)$, respectively.

$$
\text { 3. } L C C=\left\{-1.041+\frac{5.077 C}{1-A}\right\}(1-A)
$$

$\mathrm{C}$ is the carbon content, $\mathrm{M}$ and $\mathrm{N}_{\text {org }}$ are the minerals and organic nitrogen contents in total dry weight and ash content 
Table 2. Basic characteristics of wheat crop and their associated weeds (Phalaris spp., Avena spp., Chenopodium spp.)

\begin{tabular}{|c|c|c|c|c|}
\hline Traits & Wheat & Phalaris spp. & Avena spp. & Chenopodium spp. \\
\hline Life form & Annual & Annual or perennial & Annual & $\begin{array}{c}\text { Annual or perennial } \\
\text { herbs }\end{array}$ \\
\hline Family & Poaceae & Poaceae & Poaceae & Amaranthaceae \\
\hline Basal node & Greenish-yellow & $\begin{array}{c}\text { Pink in colour at } 50 \\
\text { days of growth }\end{array}$ & - & - \\
\hline Ligule & Very small & $\begin{array}{c}\text { Three times larger than } \\
\text { wheat }\end{array}$ & $\begin{array}{l}\text { membranous ligule, } \\
\text { which is } 1 \text { to } 6 \mathrm{~mm} \text { long } \\
\text { and often } \\
\text { irregularly toothed }\end{array}$ & - \\
\hline Auricle/leaf ears & $\begin{array}{c}\text { Two leaf ears/auricles } \\
\text { and hairy }\end{array}$ & No auricle & $\begin{array}{c}\text { Sheaths are smooth or } \\
\text { slightly hairy }\end{array}$ & $\begin{array}{l}\text { Toothed and roughly } \\
\text { diamond-shaped. }\end{array}$ \\
\hline Leaf colour & Dark green & Light green & Long dark green & Dark green \\
\hline Leaf size & & & $\begin{array}{l}\text { 10-40 cmlong and } \\
3-15 \mathrm{~cm} \text { wide }\end{array}$ & $\begin{array}{c}3-7 \mathrm{~cm} \text { long and } 3-6 \\
\mathrm{~cm} \text { broad }\end{array}$ \\
\hline Tillering & Erect (no branching) & $\begin{array}{l}\text { Rosette (with } \\
\text { branching) }\end{array}$ & Erect (with branching) & $\begin{array}{l}\text { Upright (with } \\
\text { branching) }\end{array}$ \\
\hline Number of seeds & $60-70$ seeds per plant & $\begin{array}{c}10000-30000 \text { seeds per } \\
\text { plant }\end{array}$ & $\begin{array}{l}\text { 1000-1500 seeds per } \\
\text { plant } \\
\text { But with interference } \\
\text { with crop produce } \\
50-1000 \text { seeds per plant }\end{array}$ & $\begin{array}{c}50,000 \text { to } 70,000 \text { seeds } \\
\text { per plant }\end{array}$ \\
\hline Grains length & 12-22mm approx. & $\begin{array}{l}1-2.5 \mathrm{~mm} \text { long } \times 1.2 \\
\text { mm wide }\end{array}$ & $11-18 \mathrm{~mm}$ & $\begin{array}{c}1.5 \mathrm{~mm} \times 1.4 \mathrm{~mm} \text { in } \\
\text { diameter, weight } 1.2 \\
\mathrm{mg} .\end{array}$ \\
\hline Test weight & $40 \mathrm{~g}$ & $2 \mathrm{~g}$ & $20-50 \mathrm{~g}$ & $\begin{array}{l}\text { Single seed weight } \\
\text { approx. } 1.2 \mathrm{mg} .\end{array}$ \\
\hline Seeds colour & Red or amber & Dark brown & Light Brown & Glossy black \\
\hline Seed shape & Oval and hard & Oval and smaller in size & Oval and hairy & $\begin{array}{l}\text { oval in cross-section } \\
\text { sides convex and } \\
\text { beak-shaped }\end{array}$ \\
\hline
\end{tabular}

\subsection{Leaf Traits of Chenopodium album}

Chenopodium album has an annual or perennial life form and the leaves are alternate, rhomboid-oval to simple ovate. The uppermost leaves are mostly lanceolate, sometimes linear and sessile, glabrous, usually white with a mealy -covering particularly on young leaves. All the leaves are densely covered with small and articulate hairs. Many of the morphological features of Chenopodium are not similar to the wheat plants, as the leaves of the wheat plant are soft and less thick than Chenopodium leaves. It is a weed of widespread occurrence in wheat fields in Northern India, Punjab and distributed all over the world and extensive work has been done on its biology and ecology. However, less research has found on the competitive ability of the Chenopodium with wheat.

\section{Variations in Leaf Functional Traits under Weed-crop Interactions}

Generally, weeds are always considered harmful plants and one of the biggest threats to agriculture $[18,19,20]$. These have more capability to attain a greater height and establish and develop extensive leaf growth and horizontal branches when moisture and nutrients are not limiting
[21,22] and also morphological and physiological characteristics, allowing it to shade and suppress the growth of its neighbours to a level that causes yield reduction [23]. Many leaf growth traits such as leaf length, leaf width and leaf area also get affected in the wheat-weed mixture [24]. Leaf growth of wheat was significantly affected due to long and droopy leaves of weeds with higher leaf angle resulting in leaf rolling which decreased the area intercepting radiation and the rate of transpiration [25].

A similar study was found in which interference of weeds (Phalaris minor Retz., Chenopodium album L, and Sinapsis arvensis L.) in spring wheat (Triticum aestivum L.) decreased flag leaf area of wheat by $14 \%$ [26]. The ability of similar weed i.e. wild oat (Avena fatua) reduced the crop yield, plant height, leaf area distribution which further decreased the light penetration to the crop canopy [27]. The upper-most leaves at the canopy of wild oats possessed a more horizontal leaf inclination than wheat [28]. The important leaf functional trait i.e. leaf area which determines the competitive ability under weeds pressure that may be due to having of more foliage (i.e. more foliage more leaf area) provided in less light penetration to the ground surface due to more competition by weeds for light, more utilization of resources and hence more dry matter accumulation [29]. As this trait increased, 
more availability of photosynthetically active surface area increased the competitive ability of weeds than wheat. Similarly, the reduction of leaf area index under weed-infested condition is a result of competitive abilities of weeds for resources that causes a decrease in wheat growth parameters and also reduces the conversion efficiency of absorbed solar radiation into dry matter accumulation [30]. Perhaps, less longevity and width of leaves lead to less leaf area which further contributed to the difference in leaf area index. Along with this, more weed density suppresses the leaf area index of wheat whereas increased its traits [31].

Nevertheless, the height and leaf area index has been strongly correlated with suppressing weed growth in rice. It has been also reported that weed such as Phalaris minor Retz. which had more leaf area, specific leaf area and leaf area ratio under high nutrient conditions as compared to the low nutrient conditions due to its highly competitive ability, nutrient use efficiency and resource accumulation which adversely affect the growth of the wheat crop [32]. Several reports showed the positive correlation of leaf area to highly competitive ability of weeds [33] and weeds particularly, Avena ludoviciana and Phalaris minor significantly suppressed the leaf area index, leaf chlorophyll content and a leaf insertion height of wheat [34,35]. A similar trend was observed in which weeds (Phalaris minor, Anagallis arvensis, Chenopodium album, Melilotus albus, Phalaris minor and Rumex dentatus) hampers the leaf weight ratio of wheat crop under weed-crop interaction which is due to variation in the weights of the leaf of the species as well the dry weight of the whole plant [32] and also leaf development and structure influence weed suppression on the crop [33, 34]. The species (Avena sativa and Phalaris minor) having high leaf weight ratio have higher rates of photosynthesis and this improves a plant's ability to compete with other plants. Leaf traits, leaf area index and leaf chlorophyll content of both wheat and weed were at par in the mixture at high nutrients condition and in monoculture at low nutrient condition, indicating higher competitiveness for the nitrogen of Avena ludoviciana [35]. Several reports were found in which more leaf area ratio in weed-crop competition indicate that there is an ability to produce more leaf area per unit dry matter for better light interception under weed-crop interaction [36,37]. The more ability of top leaves to intercept and absorb photosynthetically active radiation and also increase in relative growth rate was associated with an increase in specific leaf weight of species under agro-ecosystems [38]. Perhaps, the similarity of the growth habit between wheat and weeds and similar rooting architecture, shoot and leaf morphology, as the crop and weeds belong to same life form (grasses).
Although, weed such as Avena had thicker leaves were associated with more leaf longevity (leaf length) and construction costs [39]. However, the study showed that there was no change in leaf thickness of the crop due to weeds interference [40]. Leaves with high leaf dry matter content tend to be relatively tough and are thus assumed to be more resistant to physical hazards than leaves with low leaf dry matter content. The highly competitive capacity of these weeds with high biomass accumulation, high photosynthetic investments in leaves resulted in good resource capturing abilities (due to high specific leaf area, specific leaf area and leaf area ratio) compete with the crop. Maximum biomass allocated in the leaf or root component may increase the capturing of the limiting extrinsic resources with the interference of weeds (Avena sativa and Phalaris minor) which showed maximum ability to capture solar radiations, more rate of photosynthesis, therefore, increased production of photosynthates which enhanced the dry matter accumulation by weeds but influenced augmentation of reduction in the leaf growth of wheat crop by a certain degree of suppression [41].

\section{Efficacy of Specific Leaf Functional Traits}

Using leaf functional traits to understand plant response to environmental change is well-established for research in a wide number of natural ecosystems, and now being more widely applied to agro-ecosystems. Yet, little is known about it, or how, farm managers use the information on leaf functional traits to inform management decisions. It is not known that farmers evaluate the impacts of management based on observable and tactile characteristics of crops, some of which are directly in line with leaf functional traits under weed-crop interactions and accumulating crop functional trait data with citizen science [42]. For instance, there is reason to expect farmers who manage for greater on-farm diversity are likely to use a more detailed understanding of functional traits in decision-making. So, this includes the significance of various leaf functional traits (Table 3).

From the collected literature it was found that the competitive order proposed by the leaf functional traits analysis was consistent with the hierarchy of plant species obtained in the competition experiment. The leaf functional traits i.e. leaf length, leaf morphology, leaf angle and vertical distribution are considered to be important attributes of leaf growth and development under wheat-weed competitive ability that may be helpful to assess the efficiency of a weed. 
Table 3. Significant role of various leaf functional traits (LAD-Leaf area duration, LDMC-Leaf dry matter content, Lth-Leaf thickness, SLA-Specific leaf area, SLW-Specific leaf weight, LAR- Leaf area ratio, LN-Leaf Nitrogen, LA- leaf area, LS- Leaf size, LAI- Leaf area index, LCCLeaf Construction Cost and LWR- Leaf weight ratio)

LFTs

Significance

LAD

It denotes the magnitude and persistence leaf area during the growth period of crop and redirects the degree of seasonal integral of light interaction, the extent of photosynthetic tissue of the crop canopy and correlated with the yield.

It is the ratio of leaf dry weight to leaf fresh weight. It is also measured as TD (tissue density) which plays a central role in

LDMC the nutrient utilization of a species by determining the rate of biomass turnover (i.e. low TD is associated with the high growth rate), proxy for relative growth rate (RGR), carbon assimilation and resources accumulation.

Lth Leaf thickness plays an important part in the resource acquirement and functioning in leaf and depends upon the light absorption, diffusion pathway of $\mathrm{CO}_{2}$ and development of the leaf tissues.

SLA is an important leaf functional trait to plant growth models because it determines how much new leaf area to deploy for each unit of biomass produced. If the SLA is high, the photosynthesizing surface will be high. It is an important parameter

SLA of growth rate because the larger the SLA, the larger the area for capturing light per unit of previously captured mass. It reflects the important meanings of environmental effects on SLA. It is negatively correlated with leaf span and positively correlated with mass-based nitrogen content and photosynthetic capacity.

It is the important leaf functional trait to understand the leaf growth as is highly correlated with photosynthesis per unit of

SLW leaf area. It is a measure leaf weight per unit leaf area. More SLW indicates more biomass and a positive relationship with yield can be expected.

It is a morphological index of the plant which is closely connected with the leaf photosynthetic activity. It indicates the sign

LAR of assimilatory surface area in relation to total dry matter accumulation and tendency to produce more LA per unit dry matter for a better light interception.

LN It is a critical factor in determining plant architecture used as a measure of flowering time, a key trait for local environmental adaptation and indicates the physiological age of the plant.

The amount of tissue the plant "decides" to expose to the environment. It is a balancing act that plants invest in leaves comes down to how much leaf surface they want to expose in order to maximize the rate of photosynthesis, and how much water

LA they can afford to lose to the atmosphere through transpiration. It is one of the leaf structural traits which helps to determine the crop growth rate during the initial stages of development and is related the metabolic processes of the plant has photosynthesis and respiration and more importantly LA is important for physiological and agronomical studies. Leaf size includes leaf length and leaf width, where LL is one of the important functional traits of the leaf component which express morphological growth of the plant. It helps to determine the effect of overall resources such as water and nutrients. Also, it declines due to overall resources limitation in stressful environments, making the construction of large leaves with extensive vascular and cell-wall fractions overly expensive. It is associated with major changes in within-leaf support investments and large modifications in integrated leaf chemical and structural characteristics. These size-dependent alterations can importantly affect general leaf structure vs. function scaling relationships.

LAI LAI is the key leaf functional trait which helps to determine the atmosphere ecosystem interactions and global change controlling eco-physiology, biological and physical processes in plant canopies.

LCC It is defined as a quantifiable measure of energy invested by a plant to construct biomass, and therefore can be related to resource utilization efficiency reflecting the integral efficiency of light energy conversion

LWR It helps to understand the competitive functional attributes in the plant.
Similarly, extended maintenance of green leaf area has also been related to increasing wheat yield and parameterization of relative leaf cover is used to predict the yield loss between weed and crop [43]. Similarly, it has been associated with variables as varied as net photosynthesis [44], relative growth rate [45], yield [46] and leaf structure $[47,48]$. Moreover, increase in leaf area causes an increase in capturing of solar radiation in the canopy and enhances the dry matter accumulation and decrease in leaf area index reduces the conversion efficiency of absorbed solar radiation into dry matter accumulation [49]. Traits such as fast germination, quick growth, high biomass, and leaf area show the competitiveness of weeds over crops [50].

Specific leaf area is an important trait in plant ecology because it is associated with many critical aspects of plant growth and survival [51]. Therefore, it is considered as an important indicator of the efficiency of the leaf biomass allocated to the production of leaf area [52]. And, it is a widely used functional trait [53], because, it is easily measurable for a variety of plant species, and is correlated with 36 exploitation of available resources, productivity, leaf life-span, and leaf quality [54]. Plants with low specific leaf area typically have longer-lived leaves and slower overall relative growth rates [55] because it influences the total amount of area available for photosynthetic capture whereas species with more SLA have short-lived leaves with high photosynthetic efficiency [56]. So, it is also an important determinant of decomposition rates and nutrient return [57]; high SLA leaves break down more quickly and is partially determined by genetic factors [58], but can also be affected by soil nutrient availability and light availability [59].

Along with these, leaf thickness adopts an essential parameter in the functioning of leaf for biomass allocation and resource utilization and plays an important role in leaf and plant functioning and is related to species' strategies of resource acquisition and use. The amount of light absorbed by a leaf, and the diffusion pathway of carbon 
dioxide through its tissues depend, at least partially, on its thickness [60]. There is an indirect relationship photosynthetic mechanism and thickness of leaves [61] and growth $[62,63]$ rates have been observed, and thicker leaves have sometimes been associated with increased longevity and construction costs [39,64]. Leaf thickness has therefore often been used as a tool to screen species and/or cultivars for productivity [65] or ecological performance. So, this parameter plays an important role in leaf and plant functioning and is related to the species' strategies of resource acquisition and use. Leaf trait, leaf area ratio is potentially taken as a photosynthesizing and respiring parameter for the plant growth analysis. It is considered as the morphological index of the leafiness and is a good indicator of the severity of competition because it is directly associated with photosynthetic tissue of the plant [66]. Another leaf functional trait is net assimilation rate considered as an index of the production efficiency of a plant, and is calculated in relationship with the total leaf area and is a measure of the average photosynthetic efficiency of leaves in producing dry matter [67].

Another leaf functional trait, leaf elongation rate (LER) was strongly and positively correlated with leaf width. The species with more rapidly elongating leaves showed a faster increase with leaf position in LER, leaf width and leaf area, higher relative leaf area expansion rates, and more biomass allocation to leaf sheaths and less to roots [68]. In a controlled environment study, that a fast leaf area expansion rate in wheat was positively correlated with aboveground biomass and grain yield. In a comparison of several wheat cultivars and some of their progenitors showed a negative association between leaf area and the rate of photosynthesis per unit leaf area has been found, counteracting the positive effect of an increased leaf area on biomass production [69].

Leaf size which is a basic foliage physiognomic characteristic and numerous studies have tried to explain the prominent variation in leaf size at the global scale under different agro-ecosystems. In particular, increases in leaf size in warmer and more humid habitats have frequently been demonstrated [70]. These studies are in agreement with predictions from simulation experiments suggesting that variations in leaf size along the climatic gradients result from greater evaporative demand of larger leaves due to enhanced thickness of the boundary layer for energy and gaseous exchange. Similarly, leaf life span is a functional trait involved in a fundamental trade-off in plant functioning between a rapid production of biomass and efficient conservation of nutrients. The leaf growth rates viz. canopy density, leaf area index, rate of leaf area development, and leaf distribution are the leaf functional traits help to measure the weed suppressive ability of the crop [71]. Also, three such traits are SLA (specific leaf area, i.e. the ratio of leaf area to dry mass), LDMC (proportion of leaf dry mass to saturated fresh mass) and LNC (leaf nitrogen concentration) [72,73,74].
Physiological traits such as greater specific leaf area, higher photosynthetic rate, and higher nitrogen $(\mathrm{N})$ content is thought to be linked with resource capture and nutrient use efficiency, resulting in a higher relative growth rate and rapid biomass gain [75].

So, many traits are studied to know the growth analysis, among which leaf dry matter content and leaf area have been identified as important factors for analysis of vegetative growth [76]. These traits include the leaf traits viz. specific leaf area are considered as plastic trait makes an impact over the mechanistic models [77]. Leaf trait, relative leaf area expansion rate is directly proportional to the biomass allocation in leaves [68]. The capability of crop and weed to capture light is determined through their share of the canopy (leaf area index), leaf traits related to light absorption (such as specific leaf area) [78]. Nearly all functional traits have parallel progress with the hierarchy of yield of wheat [79] and relationships between functional traits and agro-ecosystem properties [80].

However, there is limited information available about the physiological attributes of a plant species that helps it to outcompete the others. Physiological traits such as higher specific leaf area, higher photosynthetic rate, and $\mathrm{N}$ content are thought to be linked with resource capture and nutrient use efficiency, resulting in a higher relative growth rate and rapid biomass gain [75]. The amount of light absorbed by a leaf, and the diffusion pathway of $\mathrm{CO}_{2}$ through its tissues depend on it if thickness at least partially or if not completely [60]. Therefore, many such leaf functional traits can be used as a tool to screen species and/or cultivars for productivity and ecological performance in their interactions.

\section{Phytochemical Interaction under Weed-crop Interactions}

Plants may inhibit the establishment and growth of neighboring plants by the mode of competition, allelopathy, or both. Differing from competition for available resources, allelopathy involves the release of allelochemicals from living or dead plants into the environment $(81,82)$. Allelopathy has shown both inhibitory and stimulatory roles in plant processes such as on seed germination, overall growth, development, reproduction, disease/weed management, cell division, or biosynthesis of photosynthetic pigments of other plants by releasing some allelochemicals, mainly secondary metabolites (83). Accordingly, the identification of allelochemicals from plants and their environments is key to understanding the plant-plant allelopathic interactions. So far, numerous allelochemicals have been investigated and identified from a variety of plant species. Depending on the plant, allelopathic substances can be released from a plant's flowers, leaves, leaf debris, and leaf mulch, stems, bark, roots, or soil surrounding the roots. Some of the chemicals 
biodegrade over time, while others can be persistent in the soil.

In cropping systems, crop plants have coexisted with specific weedy species. Many weeds are allelopathic and release allelochemicals that affect crop plants. For instance, Giant ragweed (Ambrosia trifida) is one of the most allelopathic weeds and it usually occurs on arable lands, which reduces crop productivity (84) which releases $1 \alpha$-Angeloyloxycarotol, a carotene-type sesquiterpene that inhibits the growth of wheat at a low concentration. This compound is released from giant ragweed into the soil could be a key allelochemical in giant ragweed infested wheat fields (85). The knowledge of phytotoxic compound found in various parts of the plant covered in numerous allelopathy-based literature equating phytotoxicity of a compound, but the phytochemical characteristics specifically of weeds affecting crop leaf functional traits is the assertion which is needed to be explored

\section{Conclusions}

The knowledge of the competitive characteristics related to the leaf traits become an important idea to define more sustainable management strategies, because, foliage is the most important component involved in most important function (synthesis of energy compound "carbohydrates" within a plant, therefore, the leaf is generally named as photosynthetic machinery. Thus, leaf growth traits of crops and weeds are very important because they provide better absorption of solar radiation and ground cover, reducing the potential growth of weeds and increasing the competitiveness of the crop. There are the reasons to expect from the farmers who manage for greater on-farm diversity are likely to use a more detailed understanding of functional traits in decision-making.

So, the competitive interaction of the plant species can be predicted by using different leaf functional traits. However, plant functional approaches, particularly leaf traits, reflect more insight characters to understand the structural and functional attributes of a crop and weeds under weed-crop interactions involving abiotic components under an agro-ecosystem. In this synthesis work, we found a very clear message that leaf functional traits can be a good tool for measuring the competitive ability of weed-crop interactions in the agro-ecosystems. Although, more research should be reinforced including the leaf phytochemical interactions under crop-weed competition. So, the more exposure to these traits is highly recommended to understand their mechanisms.

\section{Acknowledgements}

The authors are grateful to the Chairperson, Department of Botany, Panjab University, Chandigarh, for providing all the necessary facilities required for the work. The first author was supported by the University Grants Commission (UGC), Government of India, New Delhi in the form of Rajeev Gandhi National Fellowship (RGNF), and remaining three authors are supported by the same funding agency in form of Junior Research Fellowship [UGC Ref. No.: 507-(OBC) (CSIR-UGC NET DEC. 2016)]. The corresponding author acknowledges the Department of Science and Technology, Government of India, for support in the form of PURSE Grant.

\section{REFERENCES}

[1] Violle, C., M.L. Navas, D. Vile, E. Kazakou, C. Fortunel, I. Hummel and E. Garnier. (2007). Let the concept of trait be functional. Oikos, 116 (5): 882-892.

[2] Martin, A.R. and M.E. Isaac. (2018). Functional traits in agro-ecology: advancing description and prediction in agro-ecosystems. Journal of Applied Ecology, 5(1): 5-11.

[3] Ryser, P. and R. Notz. (1996). Competitive ability of three ecologically contrasting grass species at low nutrient supply in relation to their maximal relative growth rate and tissue density. Bulletin of Geobotanical Institute ETH (Eidgenossische Techniche Zurich), 62: 3-12.

[4] Pingali, P.I. (1999). Global wheat research in a changing world challenge and achievements. World Wheat-Facts and Trends. CIMMYT, Maxico, DF.

[5] Singh, A., R. Kaur, J.S. Kang and G. Singh. (2012). Weed dynamics in rice-wheat cropping system. Global Journal of Biology Agriculture and Health Sciences.1: 7-16.

[6] Pisal, R.R. and B.K. Sagarka. (2013). Integrated weed management in wheat with new molecules. Indian Journal of Weed Science, 45(1): 25-28.

[7] Chhokar, R.S., R.K. Sharma, A.K. Pundir and M.K. Gathala. (2012). Non chemical integrated weed management in wheat (Triticum aestivum). Indian Journal of Weed Science, 25(3): 112-116.

[8] Gupta, R.K. G.M. Listman and L. Harrington. (2003). The Rice-Wheat Consortium for the Indo Gangetic Plains: Vision and management structure. In: Addressing Resource Conservation Issues in Rice-Wheat Systems of South Asia: A Resource Book. Rice-Wheat Consortium for the Indo-Gangetic Plains. Intl. Maize and Wheat Impr. Cent., New Delhi, India. pp. 1-7.

[9] Ramesh, K., A.N. Rao and B.S. Chauhan. (2017). Role of crop competition in managing weeds in rice, wheat, and maize in India: A review. Crop Protection, 95: 14-21.

[10] Sharma, A.S., M.S. Bhullar, V.P. Singh, M. Singh and T.K. Das. (2016). Harnessing weed-fertilizer-water interactions for higher crop productivity and resource-use efficiency. Indian Journal of Fertilizers, 2 (11): 114-130.

[11] Bir, S.S. and M. Sidhu. (1975). Weed flora of cultivable lands in Punjab-maize fields in Patiala district. Acta Botanica Indica, 3(2): 136-141.

[12] Malik, R.K., V.M. Bhan, S.K. Katyal, R.S. Balyan and B.V. 
Singh. (1981). Weed management problems in rice-wheat cropping system adoption of weed control technology in north western India. In Abstracts of papers, annual conference of Indian Society of Weed Science, 2115.

[13] Singh, S., R.K. Malik, R.S. Balyan and S. Singh. (1995). Distribution of weed flora of wheat in Haryana. Indian Journal of Weed Science, 27(3-4): 114-121.

[14] Bhan, V.M. and S. Kumar. (1997). Integrated management of Phalaris minor in rice-wheat ecosystems in India. In Proceedings of International Conference on Ecological Agriculture: Towards Sustainable Development, 2: 15-17.

[15] Singh, S., R.C. Kirkwood and G. Marshall. (1999). Biology and control of Phalaris minor Retz. (Little seed canary grass) in wheat. Crop Protection, 18(1): 1-16.

[16] Malik, R.K. and S. Singh. (1995). Little seed canary grass (Phalaris minor) resistance to isoproturon in India. Weed Technology, 9(3): 419-425.

[17] Franke, A.C. and N. McRoberts, G. Marshall, R.K. Malik, S. Singh and A.S. Nehra. (2003). Survey of Phalaris minor in the Indian rice-wheat system. Experimental Agriculture, 39(3): 253-265.

[18] El-Khatib, A.A. (1999). Growth and physiological response of wild oats to the allelopathic potential of wheat. Acta Agronomy Hungarica, 47: 11-18.

[19] Blackshaw, R.E., L.J. Molnar and H.H. Janzen. (2004). Nitrogen fertilizer timing and application method affect weed growth and competition with spring wheat. Weed Science, 52(4): 614-622.

[20] Ross, D.M. and R.C. Van Acker. (2005). Effect of nitrogen fertilizer and landscape position on wild oat (Avena fatua) interference in spring wheat. Weed science, 53(6): 869-876.

[21] Dhima, K.V., I.G. Eleftherohorinos and I.B. Vasilakoglou. (2000). Interference between Avena sterilis, Phalaris minor and five barley cultivars. Weed Research, 40(6): 549-559.

[22] K.V. Dhima and I.G. Eleftherohorinos. (2001). Influence of nitrogen on competition between winter cereals and sterile oat. Weed Science, 49(1): 77-82.

[23] Pourreza, J. and A. Bahrani. (2015). Effects of nitrogen fertilizer on wild oat (Avena fatua) competition with wheat (Triticum aestivum). In 5th International Conference on Environment Science and Engineering Volume 83 of IPCBEE, 67-72.

[24] Bogale, A., K. Nefo and H. Seboka. (2011). Selection of some morphological traits of bread wheat that enhance the competitiveness against wild oat (Avena fatua L.). World Journal of Agricultural Sciences, 7(2): 128-135.

[25] Sivasankar, A., K.C. Bansal and Y.P. Abrol. (1993). Nitrogen in relation to leaf area development and photosynthesis. Proceedings-Indian National Science Academy Part B, 59: 235-235.

[26] Iqbal, J. and D. Wright. (1997). Effects of nitrogen supply on competition between wheat and three annual weed species. Weed Research, 37(6): 391-400.

[27] D.W. Cudney, L.S. Jordan, A.E. (1991). Hall. Effect of wild oat (Avena fatua) infestations on light interception and growth rate of wheat (Triticum aestivum). Weed Science, 39(2): 175-179.

[28] Barnes, P.W., Beyschalg, R. Ryel, S.D. Flint and M.M. Caldwell. (1990). Plant competition for light analyzed with a multispecies canopy model. III. Influence of canopy structure in mixtures and monocultures of wheat and wild oat. Oecologia, 82: 560-566.

[29] Mahajan, G. and L.S. Brar. (2002). Integrated management of Phalaris minor in wheat: rationale and approaches-a review. Agricultural Reviews-agricultural research communications center India, 23(4): 241-251.

[30] Sharifi, R.S., H. B. Hamlabad and J. Azimi. (2011). Plant population influence on the physiological indices of wheat (Triticum aestivum L.) cultivars. International Research Journal of Plant Science, 2(5): 137-142.

[31] Hamidi, R. and D. Mazaheri. (2012). Winter Wheat Growth and Yield Influenced by Wild Barley (Hordeum spontaneum Koch) Competition. Journal of Agricultural Science, 4(8):190.

[32] Singh, V., H. Singh and A.S. Raghubanshi. (2013). Competitive interactions of wheat with Phalaris minor or Rumex dentatus: A replacement series study. International Journal of Pest Management, 59(4): 245-258.

[33] Seavers, G.P. and K.J. Wright. (1999). Crop canopy development and structure influence weed suppression. Weed Research, 39(4): 319-328.

[34] Kumar, S. and A. Agarwal. (2010). Effect of herbicides on nitrogen removal by Phalaris minor (Triticum aestivum L.). Asian Journal of Experimental Biological Sciences, 81-84.

[35] Babu, M.B.B. and V. Jain. (2012). Effects of nitrogen on competition between wheat and grassy weeds. Indian Journal of Weed Science, 44: 53-57.

[36] Kumar. S. (2005). Physiological studies on weed control efficiency in clusterbean (Cyamopsis tetragonolaba). Master of Science (Agriculture), Thesis, University of Agricultural Sciences, Dharwad.

[37] Babu. V. (2008). Physiological studies on weed control efficiency in turmeric (Curucuma longa L.) (Doctoral dissertation, University of Agricultural Science, Dharwad).

[38] Mayisela, M.D., E.M. Ossom and R.L. Rhykerd. (2010). Influence of different groundnut (Arachis hypogaea L.) populations on physiological growth indices and yields under intercropping with a fixed sweet potato (Ipomoea batatas (L.) Lam.) population. Journal of Applied Sciences Research, 165-176.

[39] Mediavilla, S., A. Escudero and H. Heilmeier. (2001) Internal leaf anatomy and photosynthetic resource-use efficiency: interspecific and intraspecific comparisons. Tree Physiology, 21(4): 251-259.

[40] Silva, A.F., E.A. Ferreira, G. Concenço, F.A. Ferreira, I. Aspiazu, L. Galon, T. Sediyama and A.A. Silva. (2008). Sediyama and A.A. Silva. Densidade de plantas daninhas e épocas de controle sobre os componentes de rendimento da soja. Planta Daninha. Viçosa, 26: 65-71.

[41] Shipley, B. and D. Meziane. (2002). The balanced-growth hypothesis and the allometry of leaf and root biomass allocation. Functional Ecology, 16: 326-331. 
[42] Isaac, M.E. and A.R. Martin. (2019). Accumulating crop functional trait data with citizen science. Scientific Reports, 9(1): $1-8$

[43] Kropff, M.J. and H.H. Van Laar (Eds.). (1993). Modelling crop-weed interactions. International Rice Research Institute.

[44] Jolliffe, P.A., A.J.P. Tarimo and G.W. Eaton. (1990). Plant growth analysis: growth and yield component responses to population density in forage maize. Annals of Botany, 65(2): 139-147.

[45] Poorter, H. and A. Van der Werf. (1998). Is inherent variation in RGR determined by LAR at low irradiance and by NAR at high irradiance? A review of herbaceous species. In: Lambers H, Poorter H, Van Vuuren MMI, eds. Inherent variation in plant growth. Physiological mechanisms and ecological consequences. Leiden, The Netherlands: Backhuys Publishers, 309-336.

[46] Singh, B.P. and H.C. Sharma. (1984). Effect of 2, 4-D and hand weeding on weed population and growth and yield of wheat. Haryana Agricultural University Journal of Research, 14:346-9.

[47] Cambridge, M.L. and H. Lambers. (1998). Specific leaf area and functional leaf anatomy in Western Australian seagrassses. In: Lambers H, Poorter H, Van Vuuren MMI, eds. Inherent variation in plant growth. Physiological mechanisms and ecological consequences. Leiden, The Netherlands: Backhuys Publishers, 89-99.

[48] Pyankov, V.I., L.A. Ivanova and H. Lambers. (1998). Quantitative anatomy of photosynthetic tissues of plant species of different functional types in a boreal vegetation. In: Lambers H, Poorter H, Van Vuuren MMI, eds. Inherent variation in plant growth. Physiological mechanisms and ecological consequences. Leiden, The Netherlands: Backhuys Publishers, 71-87.

[49] Campillo, C., R. Fortes, M.D.H. Prieto and E.B. Babatunde. (2012). Solar radiation effect on crop production. Solar radiation, 1: 494

[50] Sardana, V., G. Mahajan, K. Jabran and B.S. Chauhan. (2017). Role of competition in managing weeds: An introduction to the special issue. Crop Protection, 95: 1-7.

[51] Shipley, B. and T.T. Vu. (2002). Dry matter content as a measure of dry matter concentration in plants and their parts. New Phytologist, 153(2): 359-364.

[52] Munier-Jolain, N.M., S.H.M. Guyot and N. A. Colbach. (2013). A 3D model for light interception in heterogeneous crop: weed canopies: model structure and evaluation. Ecological modelling, 250: 101-110.

[53] Wilson, P.J., K.E.N. Thompson and J.G. Hodgson. (1999). Specific leaf area and leaf dry matter content as alternative predictors of plant strategies. New phytologist, 143(1): $155-162$.

[54] Westoby M. (1998). A leaf-height-seed (LHS) plant ecology strategy scheme. Plant Soil, 199: 213-27.

[55] Poorter H. (1990). Interspecific variation in relative growth rate: on ecological causes and physiological consequences. In: Lambers H, Cambridge ML, Konings H, Pons TL, eds. Causes and consequences of variation in growth rate and productivity in higher plants. The Hague: SPB Academic
Publishing, 45-68, 1990.

[56] Poorter, H. and J.R. Evans. (1998). Photosynthetic nitrogen-use efficiency of species that differ inherently in specific leaf area. Oecologia, 116(1-2): 26-37.

[57] Laughlin. D.C. (2011). Nitrification is linked to dominant leaf traits rather than functional diversity. Journal of Ecology, 99:1091-1099.

[58] Scheepens, J., E. Frei and J. Stocklin. (2010). Genotypic and environmental variation in specific leaf area in a widespread Alpine plant after trans-plantation to diff erent altitudes. Oecologia, 64: 141-150.

[59] Meziane, D. and B. Shipley. (1999). Interacting determinants of specific leaf area in 22 herbaceous species: effects of irradiance and nutrient availability. Plant, Cell \& Environment, 22(5): 447-459.

[60] Syvertsen, J.P., J. Lloyd, C. McConchie, P.E. Kriedemann and G.D. Farquhar. (1995). On the relationship between leaf anatomy and $\mathrm{CO}_{2}$ diffusion through the mesophyll of hypostomatous leaves. Plant, Cell \& Environment, 18(2): 149-157.

[61] E. Garnier, J.L. Salager, G. Laurent and L. Sonie. (1999). Sonie. Relationships between photosynthesis, nitrogen and leaf structure in 14 grass species and their dependence on the basis of expression. New Phytologist, Vol. 143, No. (1), 119-129.

[62] Poorter, H. and C. Remkes. (1990). Leaf area ratio and net assimilation rate of 24 wild species differing in relative growth rate. Oecologia, 83(4): 553-559.

[63] Nielsen, S.L., S. Enriquez, C.M. Duarte and K. Sand-Jensen. (1996). Scaling maximum growth rates across photosynthetic organisms. Functional Ecology, 167-175.

[64] Westoby, M. D.S. Falster, A.T. Moles, P.A. Vesk and I.J. Wright. (2002). Plant ecological strategies: some leading dimensions of variation between species. Annual Review of Ecology, Evolution and Systematics, 33(1): 125-159.

[65] White, J.W and Montes-RC. (2005). Variation in parameters related to leaf thickness in common bean (Phaseolus vulgaris L.). Field Crop Research, 91: 7-21.

[66] Dezfooli, A. (2000), University of Guelph. Department of Crop Science, Competition between wild mustard (Sinapis arvensis L.) and spring wheat (Triticum aestivum L.). Ph.D, Dissertation.

[67] Gardner, F.P., R.B. Pearce and R.L. Mitchell. (1985). Physiology of crop plants. Iowa State Univ. Press, Ames, IA.

[68] Bultynck, L., M.W. Ter Steege, M. Schortemeyer, P. Poot and H. Lambers. (2004). From individual leaf elongation to whole shoot leaf area expansion: a comparison of three Aegilops and two Triticum species. Annals of Botany, 94(1) 99-108.

[69] Villar, R., E.J. Veneklaas, P. Jordano and H. Lambers. (2005). Relative growth rate and biomass allocation in 20 Aegilops (Poaceae) species. New Phytologist, 140: 425-437.

[70] D.L. Royer, P. Wilf, D.A. Janesko, E.A. Kowalski and D.L. Dilcher. (2005). Correlations of climate and plant ecology to leaf size and shape: potential proxies for the fossil record. American Journal of Botany, 92: 1141-1151. 
[71] Jha, P., V. Kumar, R.K. Godara and B.S. Chauhan. (2017). Weed management using crop competition in the United States: A review. Crop Protection, 95:31-37.

[72] Cunningham, S.A., B. Summerhayes and M. Westoby. (1999). Evolutionary divergences in leaf structure and chemistry, comparing rainfall and soil nutrient gradients. Ecological Monographs, 69: 569-588.

[73] Reich, P.B., D.S. Ellsworth, M.B. Walters, J.M. Vose, C. Gresham, J.C. Volin and W.D. Bowman. (1999). Generality of leaf trait relationships: a test across six biomes. Ecology,80:1955-1969.

[74] Markesteijn, L., L. Poorter and F. Bongers. (2007). Light-dependent leaf trait variation in 43 tropical dry forest tree species. American Journal of Botany, 94: 515-525.

[75] Osunkoya, O.O., D. Bayliss, F.D. Panetta and G. Vivian-Smith. (2010). Leaf trait co-ordination in relation to construction cost, carbon gain and resource-use efficiency in exotic invasive and native woody vine species. Annals of Botany, 106(2): 371-380.

[76] Radosevich, S., J. Holt and C. Ghersa. (1997). Weed ecology. New York: John Willey \& Sons, pp 589.

[77] I.A. Khan, G. Hassan, Ihsanullah and I.A. Khattak. (2007). Effect of wild oats (Avena fatua) densities and proportions on yield and yield components of wheat. Journal of Agricultural and Biological Science, 2(1): 26-31.

[78] Andrew, I.K. and J. Storkey. (2017). Using simulation models to investigate the cumulative effects of sowing rate, sowing date and cultivar choice on weed competition. Crop Protection, 95:109-115.

[79] Rose, T. and H. Kage. (2019). The Contribution of Functional Traits to the Breeding Progress of Central-European Winter Wheat Under Differing Crop Management Intensities. Frontiers in Plant Science, 10: 1521.

[80] Guiguitant, J., D. Vile, M.E. Ghanem, J. Wery and H. Marrou. (2020). Evaluation of pulse crops functional diversity supporting food production. Scientific Reports, $10: 3416$.

[81] Meiners S.J., C.H. Kong, L.M. Ladwig, N.L. Pisula and K.A. Lang. (2012). Developing an ecological context for allelopathy. Plant Ecology, 213(8): 1221-1227.

[82] Swanton, C. J., R. Nkoa and R.E. Blackshaw. (2015). Experimental methods for crop-weed competition studies. Weed Science, 63(SP1):2-11.

[83] Bachheti A., A. Sharma, R.K. Bachheti, A. Husen, D.P. Pandey. (2020) Plant Allelochemicals and Their Various Applications. In: Mérillon JM., Ramawat K. (eds) Co-Evolution of Secondary Metabolites. Reference Series in Phytochemistry. Springer, Cham.

[84] Harrison, S. K., E.E. Regnier and J.T. Schmoll. (2003). Postdispersal predation of giant ragweed (Ambrosia trifida) seed in no-tillage corn. Weed Science, 955-964.

[85] Kong, C. H., P. Wang and X.H. Xu. (2007). Allelopathic interference of Ambrosia trifida with wheat (Triticum aestivum). Agriculture, Ecosystems \& Environment, 119(3-4): 416-420.

[86] Brooking, I. R., P.D. Jamieson and Porter, J. R. (1995). The influence of daylength on final leaf number in spring wheat. Field Crops Research, 41(3), 155-165.

[87] Quarrie, S. A. and H.G.Jones. (1979). Genotypic variation in leaf water potential, stomatal conductance and abscisic acid concentration in spring wheat subjected to artificial drought stress. Annals of Botany, 44(3): 323-332.

[88] Sultana, N., T. Ikeda and M.A. Kashem. (2002). Effect of seawater on photosynthesis and dry matter accumulation in developing rice grains. Photosynthetica, 40: 115-119.

[89] Power, J. F. W.O. Willis, D.L. Grunes and G. A. Reichman, G. A. (1967). Effect of soil temperature, phosphorus, and plant age on growth analysis of barley. Agronomy Journal, 59(3), 231-234.

[90] Tavakoli, H., S.S. Mohtasebi, R. Alimardani and R. Gebbers. (2014). Evaluation of different sensing approaches concerning to nondestructive estimation of leaf area index (LAI) or winter Wheat. International Journal on Smart Sensing \& Intelligent Systems, 7(1).

[91] Simon, M. R. (1999). Inheritance of flag-leaf angle, flag-leaf area and flag-leaf area duration in four wheat crosses. Theoretical and Applied Genetics, 98(2): 310-314.

[92] Holt, J. S., and D.R. Orcutt. (1991). Functional relationships of growth and competitiveness in perennial weeds and cotton (Gossypium hirsutum). Weed Science, 575-584.

[93] Seibert, A. C., and R. B. Pearce. (1993). Growth analysis of weed and crop species with reference to seed weight. Weed Science: $52-56$.

[94] Salehian, H., and O. Eshaghi. (2012). Growth analysis some weed species. International Journal of Agriculture and Crop Sciences (IJACS), 4(11): 730-734.

[95] Singh, V., H. Singh and A. S. Raghubanshi. (2013). Competitive interactions of wheat with Phalaris minor or Rumex dentatus: A replacement series study. International Journal of Pest Management, 59(4): 245-258.

[96] Bowyer, P., and F.M. Danson. (2004). Sensitivity of spectral reflectance to variation in live fuel moisture content at leaf and canopy level. Remote Sensing of Environment, 92(3): 297-308.

[97] Perez-Harguindeguy, N., S. Diaz, E. Gamier, S. Lavorel, H. Poorter, P. Jaureguiberry, M.S. Bret-Harte, W.K. Comwell, J.M. Craine, D.E. Gurvich and C. Urcelay. (2013). New handbook for stand-ardised measurement of plant functional traits worldwide. Australian Journal of Botany, 61: 167-234.

[98] Causton, D. R. (1994). Plant growth analysis: a note on the variability of unit leaf rate (net assimilation rate) within a sample. Annals of Botany, 74(5): 513-518.

[99] Dhopte, A.M. and L.M. Manuel. (2002). Principles and techniques for plant scientists. 1st Ed., Updesh Purohit for Agrobios (India), pp. 373.

[100] Barrs, H. D. and P.E. Weatherley. (1962). A re-examination of the relative turgidity technique for estimating water deficits in leaves. Australian Journal of Biological Sciences, 15(3): 413-428

[101] Pieczynski, M., W. Marczewski, J. Hennig, J. Dolata, D. Bielewicz, P. Piontek, A. Wyrzykowska, D. Krusiewicz, D. Strzelczyk - Zyta, D. Konopka - Postupolska, and M. 
Krzeslowska, (2013). Down - regulation of CBP 80 gene expression as a strategy to engineer a drought - tolerant potato. Plant Biotechnology Journal, 11(4): 459-469.

[102] Navas, M. L., B. Ducout, C. Roumet, J. Richarte, J. Garnier and E. Garnier. (2003). Leaf life span, dynamics and construction cost of species from Mediterranean old-fields differing in successional status. New Phytologist, 159(1), 213-228.

[103] Vertregt, N. F. W. T. and F.P. De Vries. (1987). A rapid method for determining the efficiency of biosynthesis of plant biomass. Journal of Theoretical Biology, 128(1), 109-119.

[104] Williams, K., C.B. Field and H.A. Mooney. (1989). Relationships among leaf construction cost, leaf longevity, and light environment in rain-forest plants of the genus Piper. The American Naturalist, 133(2): 198-211.

[105] Poorter, H. (1994). Construction costs and payback time of biomass: a whole plant perspective. A whole plant perspective on carbon-nitrogen interactions, 111-127. 